\title{
CONTROL OF BROWN SPOT PATHOGEN OF RICE (BIPOLARIS ORYZAE) USING SOME PHENOLIC ANTIOXIDANTS
}

\author{
Y.M. Shabana ${ }^{1}$; G.M.Abdel-Fattah ${ }^{2}$; A.E. Ismail ${ }^{3}$;.M. Rashad ${ }^{2}$ \\ ${ }^{1}$ Department of Plant Pathology, Faculty of Agriculture, Mansoura University, El-Mansoura, Egypt; ${ }^{2}$ Department of Botany, \\ Faculty of Science, Mansoura University, El-Mansoura, Egypt; ${ }^{3}$ Department of Mycological Research and Disease Survey, \\ Plant Pathology Institute, Agricultural Research Center, Giza, Egypt.
}

Submitted: July 24, 2007; Returned to authors for corrections: January 21, 2008; Approved: July 06, 2008.

\begin{abstract}
Bipolaris oryzae is the causal agent of rice brown spot disease and is responsible for significant economic losses. In order to control this disease, three phenolic antioxidants were tested (salicylic acid, benzoic acid and hydroquinone). The antifungal activity of the tested substances were investigated against $B$. oryzae at different concentrations in vitro, as well as the efficacy of their exogenous application in controlling rice brown spot disease under field conditions. In vitro, benzoic acid or salicylic acid at $9 \mathrm{mM}$ completely inhibited the growth of $B$. oryzae. Under field conditions, spraying of benzoic acid at $20 \mathrm{mM}$ led to a significant reduction in disease severity (DS) and disease incidence (DI) on the plant leaves, in addition to a significant increase in the grain yield and its components. Some biochemical responses were also detected, where the application of the previous treatment led to a significant increase in the total photosynthetic pigments (chlorophyll $a$ and $b$ and carotenoids) in rice leaves and in the total carbohydrate and protein contents of the yielded grains.
\end{abstract}

Key-words: Benzoic acid, Bipolaris oryzae, Hydroquinone, Salicylic acid, Systemic resistance.

\section{INTRODUCTION}

Bipolaris oryzae is classified in the subdivision Deuteromycotina (imperfect fungi), class Deuteromycetes, order Moniliales, and family Dematiaceae and is the causal agent of brown spot disease of rice. Brown spot is one of the important rice diseases in the world. In Egypt, the disease comes in the second rank after blast disease (7). It can be a serious disease causing a considerable yield loss. Where, it affects the quality and the number of grains per panicle and reduces the kernel weight (16). Rice (Oryza sativa L.) is among the most important cereals in Egypt. It is rated the second exported crop after cotton. The cultivated area under rice amount to 613,300 hectare produced 6,500,000 ton in 2007 (9). Chemical control may be available to reduce the effects of brown spot disease on young plants effectively and extensively, but field application of these chemical fungicides may not always be desirable. Excessive and improper use of these fungicides presents a menace to the health of humans, animals and environment. Many of these chemicals are also too expensive for the resource of poor farmers. As an alternative to chemical fungicides, three safe phenolic antioxidants were tested in this work, salicylic acid, benzoic acid and hydroquinone. In this connection, salicylic acid was applied as a foliar spray and led to reduction in the incidence of chocolate spot disease of faba bean caused by Botrytis fabae (1). For damping-off control, benzoic acid inhibited Rhizoctonia solani growth in vitro and efficiently controlled both pre-emergence damping-off and post-emergence seedling mortality of Phaseolus vulgaris. Benzoic acid, salicylic acid, sodium benzoate and hydroquinone were tested against the seed borne fungi of peanut i.e. Cephalosporium sp., Fusarium moniliforme, F. oxysporum, R. solani, Sclerotium bataticola and Verticillium sp. The most effective antioxidant was hydroquinone (8).

*Corresponding Author. Mailing address: Department of Botany, Faculty of Science, Mansoura University, El-Mansoura, Egypt 35516. Fax: 002 050 224 6781. Tel.: 002050224 2388. E-mail: younesrashad@yahoo.com 
Although it is toxic in large quantities, salicylic acid is used as a food preservative, antiseptic in toothpaste, as a key ingredient in many skin-care products, and in preparation of Aspirin. The medicinal properties of salicylate, mainly for fever relief, have been known since ancient times, and it was used as an anti-inflammatory drug (15).

Benzoic acid occurs naturally free and bound in many plant and animal species. Since benzoic acid inhibits the growth of fungi (22) and some bacteria, it is used as a food preservative and in the treatment of fungal skin diseases.

This work was aimed to study the effect of salicylic acid, benzoic acid and hydroquinone on the growth of $B$. oryzae in vitro, then field evaluation for the most effective treatments obtained from bench scale results in controlling rice brown spot disease. Finally, determination of some biochemical changes in rice plants as a response of treating with the phenolic substances.

\section{MATERIALS AND METHODS}

\section{Isolation of the pathogen}

Naturally diseased leaves of different rice cultivars infected in varied degrees with brown spot were collected from various districts in Dakahlia governorate, Egypt. Thirteen isolates of the fungal pathogen were isolated and purified using single spore technique. Identification of the purified cultures was carried out according to the cultural properties, morphological and microscopical characteristics described by Mew \& Gonzales (16).

\section{Pathogenicity test}

Rice grains (Giza 177), the most common cultivar in Egypt, were obtained from Central Administration for Seed Certification, Ministry of Agriculture, Egypt and used in both green house and field experiments. Rice seedlings were sprayed at 21-day-old under greenhouse conditions with the spore suspension $\left(5 \times 10^{5}\right.$ spore. $\left.\mathrm{ml}^{-1}\right)$ of the thirteen isolates of $B$. oryzae separately. The seedlings were sprayed until runoff occurred. Five replicates were used for each isolate. Disease severity (DS) and disease incidence (DI) were assessed. DS was estimated according to the disease index established by Aluko (3).

\section{In vitro experiments}

Effect of the tested antioxidants on the linear growth of B. oryzae

Three phenolic antioxidants (salicylic acid, benzoic acid and hydroquinone obtained from El-Nasr Pharmaceutical Chemicals Co., Egypt) were used to study their effects on the linear growth of $B$. oryzae on agar plates. Six concentrations $(0,3,6,9,12$ and $15 \mathrm{mM}$ ) of each substance were incorporated in Potato Dextrose Agar (PDA) by adding the appropriate amount of each substance aseptically to the melted medium just before solidification. Plates containing $20 \mathrm{ml}$ of the medium at each concentration were prepared. Disks ( $7 \mathrm{~mm}$ in diameter) taken from the growing edge of 5-day-old colony of $B$. oryzae were used to inoculate the prepared plates. For each treatment, seven replicates were used. The plates were incubated at $25 \pm 2^{\circ} \mathrm{C}$ for 6 days. The linear growth of $B$. oryzae in each treatment was measured 2, 4 and 6 days after inoculation.

\section{Field evaluation of the phenolic antioxidants against the brown spot disease}

Plots (each of $3.5 \times 1.5 \mathrm{~m}$ ) were ploughed well, all weeds removed, soil were leveled and nitrogen fertilizer (Urea 46\%) and phosphorous $\left(15 \% \mathrm{P}_{2} \mathrm{O}_{5}\right.$, Super phosphate) were added at the recommended doses. Thirty-day-old seedlings (Giza 177) naturally infected with brown spot were transplanted at the spacing $20 \times 20 \mathrm{~cm}$. Salicylic acid or benzoic acid at 5,10 or 20 $\mathrm{mM}$ were sprayed separately four times at 15-day intervals beginning from 30-days after transplanting. Four plots were used for each treatment. Four plots were sprayed with the chemical fungicide Hinosan at the recommended dose (952 $\mathrm{ml} \mathrm{ha}^{-1}$ ) to serve as a positive control. Another four plots were sprayed with plain water to serve as a negative control. The plants were sprayed until run-off occurred. The plots were arranged in a completely randomized design.

\section{Monitoring of DS, DI, grain yield and grain quality}

DS and DI were estimated three times at 7-day intervals after the first spraying. At maturity stage, 25 rice plants were randomly selected from the middle part of each plot, by leaving two rows from each side to avoid border effect, and plant height, panicle length, number of panicle branches and number of grains per panicle were determined. Rice grains harvested from all treatments were subjected to standard blotter method (13) and evaluated for the incidence of $B$. oryzae.

Photosynthetic pigments (Chlorophyll $a$, Chlorophyll $b$ and Carotenoids) were estimated in the leaves using the spectrophotometric method as described by Harborne (11). Rice grains were oven dried at $80^{\circ} \mathrm{C}$ to a constant weight and ground to a fine powder with electric grinder. The method used for estimation of total carbohydrates was that of Hedge \& Hofreiter (13). While, the method of protein extraction followed is that described by Scarponi \& Perucci (20). Finally, protein content in the extract was determined according to the method adopted by Bradford (4).

\section{Statistical analysis}

Data were analyzed with the statistical analysis software SAS Institute (18). All Data were first subjected to analysis of variance (ANOVA). Comparisons among means were made using Duncan's multiple range test (6) at $P=0.05$. 


\section{RESULTS}

\section{Pathogenicity test}

By the end of the isolation trials for the causal agent of brown spot disease from diseased rice leaves, thirteen fungal isolates were obtained and identified as $B$. oryzae. Of which $B$. oryzae $\mathrm{B} 5$ showed the highest DS on rice cultivar Giza 177 (data not shown). So this isolate was considered to be the most aggressive one and selected for further studies.

\section{In vitro results}

\section{Effect of some phenolic antioxidants on the linear growth of} B. oryzae

Salicylic acid, Benzoic acid and Hydroquinone were tested against the linear growth of B. oryzae at different concentrations $(3,6,9,12$ and $15 \mathrm{mM})$. It was found that there is an inverse relationship between the concentration of the phenolic substances and the linear growth of B. oryzae i.e. as the concentration increases the linear growth decreases. Benzoic acid and salicylic acid were the most effective inhibitors for the growth of B. oryzae compared with the control (Fig. 1). Where at $9 \mathrm{mM}$, they completely inhibited the linear growth of B. oryzae. In this connection, hydroquinone comes at the end even at high concentrations.

\section{Field evaluation of the phenolic antioxidants against the brown spot disease}

In order to evaluate the tested substances under field conditions, benzoic acid and salicylic acid (the most effective antioxidants under lab. conditions) were sprayed at three concentrations $(5,10$ and $20 \mathrm{mM})$. The application of benzoic acid at $20 \mathrm{mM}$ recorded the lowest values of DS and DI on rice leaves. Table 1 showed that there were no significant differences in DS among all treatments at $7^{\text {th }}$ day after the first application, while there were significant differences between them with regard to the DI. However, at $14^{\text {th }}$ day after the application, significant differences in DS were observed between the rice plots, where those treated with benzoic acid at $20 \mathrm{mM}$ or Hinosan showed the lowest DS (2.8). At the same time, rice plots that were treated with benzoic acid at $20 \mathrm{mM}$ showed the lowest DI. After 21 days, the rice plots that were treated with benzoic acid at $20 \mathrm{mM}$ or Hinosan showed the lowest value of DS (2.5). With regard to DI, rice plots that were treated with benzoic acid at 20 $\mathrm{mM}$ showed the lowest DI (48.5\%). There was no relationship between DI and DS since, disease can occur with high percentage on the plant although its severity may be low.

No significant differences were recorded in the investigated growth parameters (plant height, panicle length and number of panicle branches) between treated and untreated rice plants (data not shown). While, the treatment with benzoic acid at 20 $\mathrm{mM}$ or Hinosan produced the highest number of filled grains and also the lowest number of unfilled grains per panicle, the

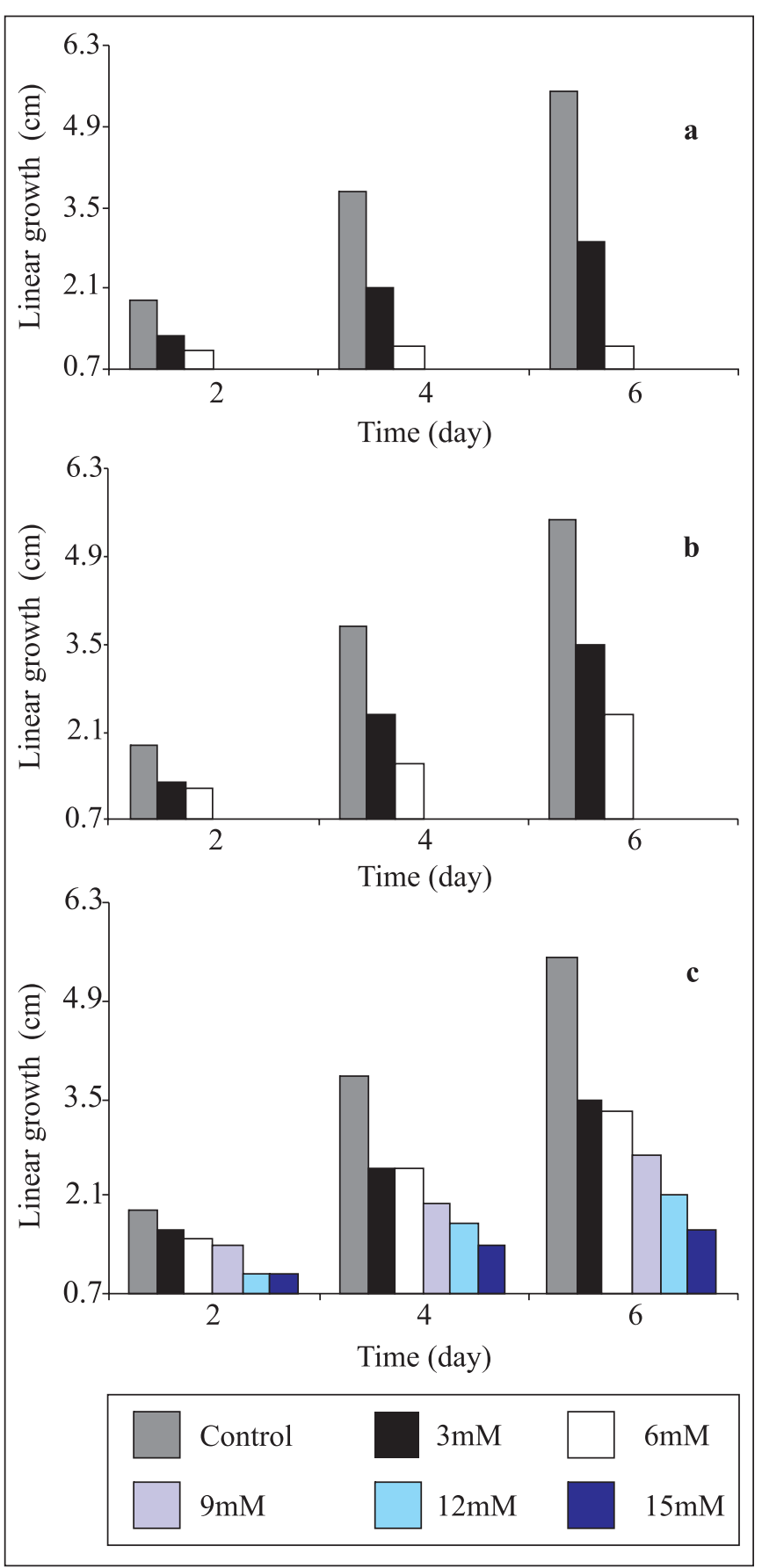

Figure 1. Effect of different phenolic substances on the linear growth of B. oryzae, salicylic acid (a), benzoic acid (b) and hydroquinone $\mathrm{c}$ ).

highest panicle weight, the highest 1000 grain weight and the highest grain yield when compared with the untreated control as showed in Table 2. Moreover, treatment of rice plots with benzoic acid at $20 \mathrm{mM}$ or Hinosan showed the minimum 
Table 1. Effect of different treatments on disease incidence (DI) and disease severity (DS) of rice brown spot in the field.

\begin{tabular}{|c|c|c|c|c|c|c|c|}
\hline \multirow{3}{*}{ Treatment } & & \multicolumn{6}{|c|}{ Days after the first application } \\
\hline & & \multicolumn{2}{|c|}{7} & \multicolumn{2}{|c|}{14} & \multicolumn{2}{|c|}{21} \\
\hline & & DI $(\%)$ & DS & DI $(\%)$ & DS & DI $(\%)$ & DS \\
\hline Control & & $59.5 \mathrm{a}^{*}$ & $4 \mathrm{a}$ & $65.2 \mathrm{a}$ & $4.5 \mathrm{a}$ & $70.3 \mathrm{a}$ & $4.5 \mathrm{a}$ \\
\hline Hinosan & & $58.3 \mathrm{a}$ & $3.3 \mathrm{a}$ & $56.9 \mathrm{bc}$ & $2.8 \mathrm{c}$ & $50.5 \mathrm{~cd}$ & $2.5 \mathrm{~d}$ \\
\hline Salicylic acid (mM) & $\begin{array}{c}5 \\
10 \\
20\end{array}$ & $\begin{array}{c}58.3 \mathrm{a} \\
57.7 \mathrm{ab} \\
55.4 \mathrm{~b}\end{array}$ & $\begin{array}{c}4 \mathrm{a} \\
4 \mathrm{a} \\
3.8 \mathrm{a}\end{array}$ & $\begin{array}{c}59.2 \mathrm{~b} \\
53.4 \mathrm{~cd} \\
48.6 \mathrm{~d}\end{array}$ & $\begin{array}{c}4 \mathrm{ab} \\
3.8 \mathrm{abc} \\
3.5 \mathrm{abc}\end{array}$ & $\begin{array}{c}58.1 \mathrm{~b} \\
50.1 \mathrm{~cd} \\
47.8 \mathrm{~d}\end{array}$ & $\begin{array}{c}4 \mathrm{ab} \\
3.5 \mathrm{bc} \\
3.3 \mathrm{bcd}\end{array}$ \\
\hline Benzoic acid $(\mathrm{mM})$ & $\begin{array}{c}5 \\
10 \\
20\end{array}$ & $\begin{array}{c}57.2 \mathrm{ab} \\
55.1 \mathrm{~b} \\
55.2 \mathrm{~b}\end{array}$ & $\begin{array}{c}3.8 \mathrm{a} \\
3.3 \mathrm{a} \\
3 \mathrm{a}\end{array}$ & $\begin{array}{c}56.3 \mathrm{bc} \\
50.6 \mathrm{~d} \\
50.3 \mathrm{~d}\end{array}$ & $\begin{array}{c}3.8 \mathrm{abc} \\
3 \mathrm{bc} \\
2.8 \mathrm{c}\end{array}$ & $\begin{array}{l}56.5 \mathrm{~b} \\
48.6 \mathrm{~d} \\
48.5 \mathrm{~d}\end{array}$ & $\begin{array}{c}3.8 \mathrm{abc} \\
3 \mathrm{~cd} \\
2.5 \mathrm{~d}\end{array}$ \\
\hline
\end{tabular}

* Values within a column followed by the same letter(s) are not significantly different at $P=0.05$.

pathogen incidence on resulted grains ( 5 and $4 \%$, respectively) as showed in Fig. 2.

\section{Biochemical changes in rice plants}

Some biochemical changes in the rice plants were also determined. Treatment of rice plants with benzoic acid at $20 \mathrm{mM}$

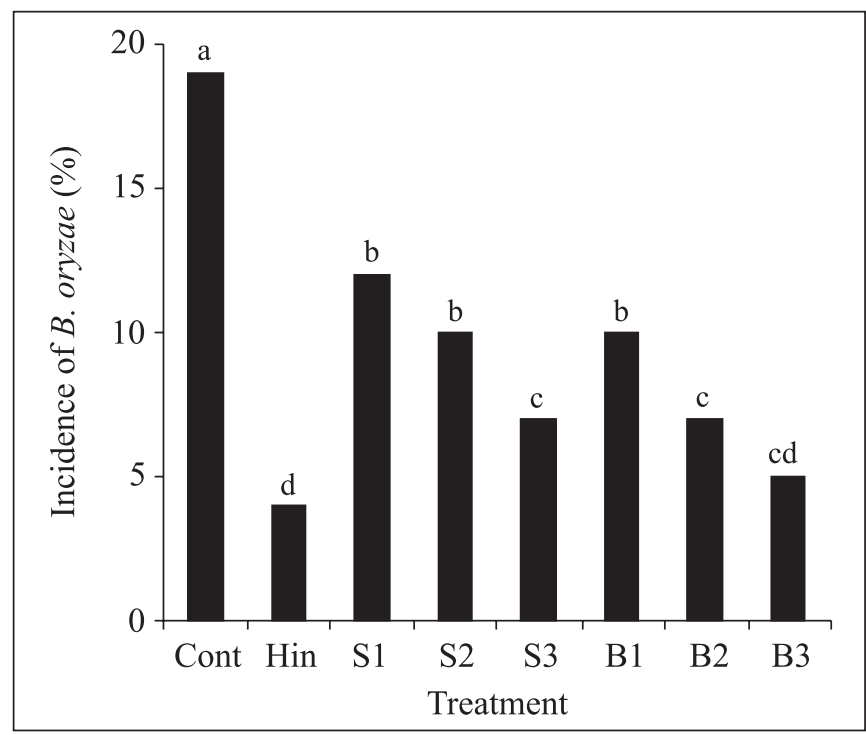

Figure 2. Effect of treatments on the incidence of B. oryzae on yielded rice grains. Where, $\mathrm{Cont}=$ control, $\mathrm{Hin}=$ Hinosan at 952 $\mathrm{ml} \cdot \mathrm{ha}^{-1}, \mathrm{~S} 1=$ salicylic acid at $5 \mathrm{mM}, \mathrm{S} 2=$ salicylic acid at $10 \mathrm{mM}$, $\mathrm{S} 3=$ salicylic acid at $20 \mathrm{mM}, \mathrm{B} 1=$ benzoic acid at $5 \mathrm{mM}$, B2 $=$ benzoic acid at $10 \mathrm{mM}$ and $\mathrm{B} 3=$ benzoic acid at $20 \mathrm{mM}$. Columns superscripted with the same letter(s) are not significantly different at $P=0.05$. or Hinosan resulted in the maximum total photosynthetic pigments, namely 1.06 and $1.05 \mathrm{mg} \cdot \mathrm{g}^{-1}$ fresh weight, respectively (Table 3), the highest significant increase in total carbohydrate content, namely 562 and $530.7 \mathrm{mg} . \mathrm{g}^{-1}$ dry wt., respectively (Fig. 3 ), and the maximum protein content, namely 65.4 and $64.6 \mathrm{mg} . \mathrm{g}$ ${ }^{1}$ dry wt., respectively (Fig. 4).

\section{DISCUSSION}

Decreasing the use of chemical fungicides is one of important aims in plant pathology. One of promising lines in this area is increasing the plant resistance to microbial pathogens by using

Table 2. Effect of different treatments on the grain yield of rice plants infected with brown spot disease under field conditions.

\begin{tabular}{ccccccc}
\hline Treatment & $\begin{array}{c}\text { No. of } \\
\text { filled } \\
\text { grains. } \\
\text { panicle }\end{array}$ & $\begin{array}{c}\text { No. of } \\
\text { unfilled } \\
\text { grains. } \\
\text { panicle }\end{array}$ & $\begin{array}{c}\text { Panicle } \\
\text { weight } \\
(\mathrm{g})\end{array}$ & $\begin{array}{c}1000 \\
\text { grain } \\
\text { weight } \\
(\mathrm{g})\end{array}$ & $\begin{array}{c}\text { Grain } \\
\text { yield } \\
\text { (ton. } \\
\text { ha }^{-1} \text { ) }\end{array}$ \\
\hline Control & $91.3 \mathrm{~g}^{*}$ & $10.5 \mathrm{a}$ & $2.4 \mathrm{~d}$ & $23.3 \mathrm{de}$ & $6.4 \mathrm{ef}$ \\
Hinosan & & $107.1 \mathrm{ab}$ & $6.3 \mathrm{e}$ & $2.7 \mathrm{ab}$ & $26.8 \mathrm{a}$ & $7.3 \mathrm{a}$ \\
Salicylic & 5 & $101.9 \mathrm{de}$ & $9.7 \mathrm{~b}$ & $2.5 \mathrm{~cd}$ & $24.1 \mathrm{~cd}$ & $6.5 \mathrm{e}$ \\
acid (mM) & 10 & $103.5 \mathrm{~cd}$ & $8.1 \mathrm{c}$ & $2.5 \mathrm{~cd}$ & $24.7 \mathrm{c}$ & $6.9 \mathrm{c}$ \\
& 20 & $106.2 \mathrm{bc}$ & $7.3 \mathrm{~d}$ & $2.6 \mathrm{bc}$ & $25.4 \mathrm{bc}$ & $7.1 \mathrm{~b}$ \\
Benzoic & 5 & $102.3 \mathrm{~d}$ & $9.6 \mathrm{~b}$ & $2.4 \mathrm{~d}$ & $24.3 \mathrm{~cd}$ & $6.6 \mathrm{de}$ \\
acid (mM) & 10 & $107.4 \mathrm{ab}$ & $8.1 \mathrm{c}$ & $2.6 \mathrm{bc}$ & $25.8 \mathrm{~b}$ & $7.0 \mathrm{bc}$ \\
& 20 & $108.4 \mathrm{a}$ & $7.3 \mathrm{~d}$ & $2.7 \mathrm{ab}$ & $26.7 \mathrm{a}$ & $7.3 \mathrm{a}$ \\
\hline
\end{tabular}

*Values within a column followed by the same letter(s) are not significantly different at $P=0.05$. 
Table 3. Photosynthetic pigments (mg.g ${ }^{-1}$ fresh weight) in infected rice leaves treated with different treatments.

\begin{tabular}{cccccc}
\hline Treatment & Chl. $a$ & Chl. $b$ & Carotenoids & $\begin{array}{c}\text { Total } \\
\text { pigments }\end{array}$ \\
\hline Control & & $0.46 \mathrm{de} *$ & $0.31 \mathrm{c}$ & $0.02 \mathrm{~d}$ & $0.79 \mathrm{~cd}$ \\
Hinosan & & $0.56 \mathrm{a}$ & $0.43 \mathrm{a}$ & $0.06 \mathrm{a}$ & $1.05 \mathrm{a}$ \\
Salicylic & 5 & $0.49 \mathrm{~cd}$ & $0.33 \mathrm{bc}$ & $0.02 \mathrm{~d}$ & $0.84 \mathrm{c}$ \\
acid (mM) & 10 & $0.51 \mathrm{bc}$ & $0.31 \mathrm{c}$ & $0.03 \mathrm{~cd}$ & $0.85 \mathrm{c}$ \\
& 20 & $0.53 \mathrm{~b}$ & $0.39 \mathrm{ab}$ & $0.04 \mathrm{bc}$ & $0.96 \mathrm{~b}$ \\
Benzoic & 5 & $0.50 \mathrm{c}$ & $0.31 \mathrm{c}$ & $0.03 \mathrm{~cd}$ & $0.84 \mathrm{c}$ \\
acid (mM) & 10 & $0.53 \mathrm{~b}$ & $0.40 \mathrm{ab}$ & $0.03 \mathrm{~cd}$ & $0.96 \mathrm{~b}$ \\
& 20 & $0.56 \mathrm{a}$ & $0.39 \mathrm{ab}$ & $0.04 \mathrm{bc}$ & $1.06 \mathrm{a}$ \\
\hline
\end{tabular}

*Values within a column followed by the same letter(s) are not significantly different at $P=0.05$.

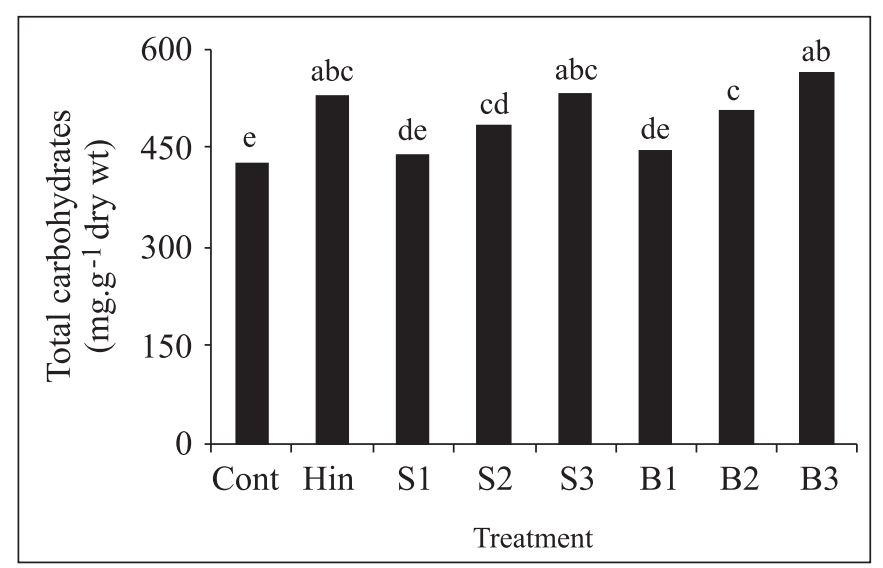

Figure 3. Effect of treatments on total carbohydrates in rice grains. Where, cont $=$ control, $\mathrm{Hin}=$ Hinosan at $952 \mathrm{ml}^{-\mathrm{ha}^{-1}}, \mathrm{~S} 1$ $=$ salicylic acid at $5 \mathrm{mM}, \mathrm{S} 2=$ salicylic acid at $10 \mathrm{mM}, \mathrm{S} 3=$ salicylic acid at $20 \mathrm{mM}, \mathrm{B} 1=$ benzoic acid at $5 \mathrm{mM}, \mathrm{B} 2=$ benzoic acid at $10 \mathrm{mM}$ and $\mathrm{B} 3=$ benzoic acid at $20 \mathrm{mM}$. Columns superscripted with the same letter(s) are not significantly different at $P=0.05$.

biotic or a biotic agents. Phenolics are well-known antifungal, antibacterial and antiviral compounds occurring in plants (12). In vitro, benzoic acid and salicylic acid were found to be the most effective inhibitors for the growth of $B$. oryzae. Where at $9 \mathrm{mM}$, they completely inhibited the growth of $B$. oryzae. Those findings are in agreement with those of Shahda (22) on Fusarium oxysporum, F. solani and Rhizoctonia solani isolated from tomato plants. Cowan (5) explained the mechanisms thought to be responsible for the phenolics toxicity to microorganisms on

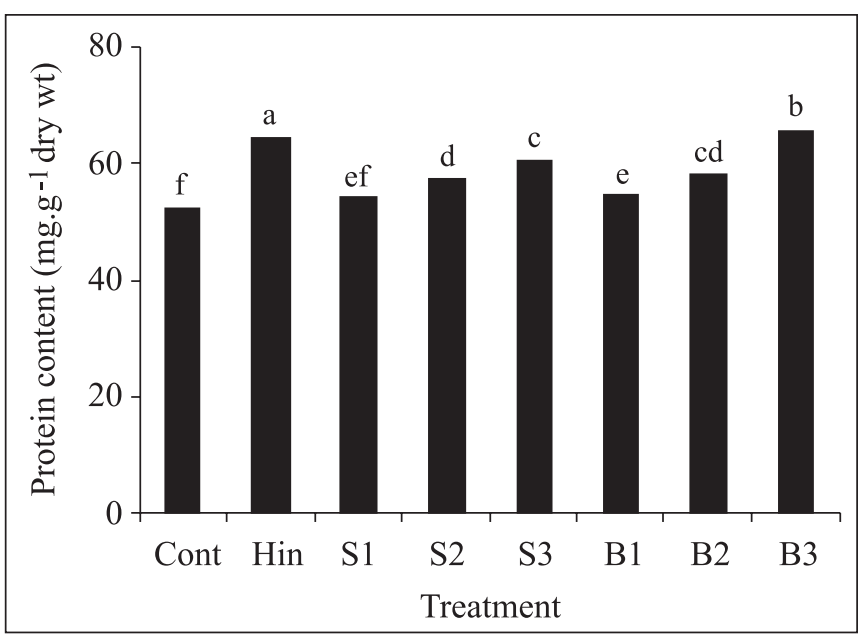

Figure 4. Effect of treatments on protein content in rice grains. Where, cont $=$ control, Hin $=$ Hinosan at $952 \mathrm{ml} \cdot \mathrm{ha}^{-1}, \mathrm{~S} 1=$ salicylic acid at $5 \mathrm{mM}, \mathrm{S} 2=$ salicylic acid at $10 \mathrm{mM}, \mathrm{S} 3=$ salicylic acid at $20 \mathrm{mM}, \mathrm{B} 1=$ benzoic acid at $5 \mathrm{mM}, \mathrm{B} 2=$ benzoic acid at $10 \mathrm{mM}$ and $\mathrm{B} 3=$ benzoic acid at $20 \mathrm{mM}$. Columns superscripted with the same letter(s) are not significantly different at $P=0.05$.

the basis of enzyme inhibition by the oxidized compounds, possibly through reaction with sulfohydryl groups or through more nonspecific interactions with the proteins. The site(s) and number of hydroxyl groups on the phenol group are thought to be related to their relative toxicity to microorganisms, with evidence that increased hydroxylation results in increased toxicity. In addition, some investigators have found that the more highly oxidized phenols the more inhibitory effect to a pathogen (19).

Under field conditions, treatment with benzoic acid at 20 $\mathrm{mM}$ was the best. Where, rice plants showed the lowest level of DI and DS. Moreover, the same treatment produced the maximum number of filled grains per panicle and decreased number of unfilled grains per panicle when compared with the control. They also recorded a significant increase in the panicle weight, 1000 grain weight and grain yield. A significant reduction in the incidence of $B$. oryzae on grains obtained from treated rice plants was also recorded. These results agree with the findings of Abbas et al. (1) against chocolate spot disease of faba bean. Salicylic acid is a phytohormone; and has a significant impact on plant growth and development, and is recognized as an endogenous signal, mediating in plant defense, against pathogens. Where in the pathogen-induced pathway, systemic acquired resistance (SAR) is mediated by an endogenous signal that is produced in the infected leaf and translocated in the phloem to other plant parts, where it activates resistance mechanisms (12). These coupling with the finding that exogenous salicylic acid could induce SAR (24) and SAR gene 
expression, led to the suggestion that salicylic acid was involved in SAR signaling. Salicylic acid-induced pathway is characterized by the production of a cascade of pathogenesis related proteins. Where a number of biochemical and physiological changes has been associated with pathogen infection. These include: 1 . the production of antifungal chitinases, glucanases and thaumatins, and oxidative enzymes such as peroxidases, polyphenol oxidases and lipoxygenases; 2. Low molecular weight compounds with antimicrobial properties (phytoalexins) can also accumulate (23); 3 . cell death and deposition of callose and lignin (10); and 4. forming novel proteins (17).

Because exogenous application of benzoic acid causes salicylic acid accumulation (25), it seems plausible that the ratelimiting step in salicylic acid biosynthesis is the conversion of trans-cinnamic acid to benzoic acid, although other possibilities exist. In bean and tomato plants, benzoic acid may act as the functional group in salicylic acid and its derivatives in the induction of multiple stress tolerance in plants (21).

As foliar pathogens, B. oryzae affects the photosynthetically active tissues of rice. It may reduce the rate of the photosynthesis in the infected leaves by affecting either the chloroplasts or chlorophyll content directly, or through the enzymes concerned with photosynthesis (2). On the other hand, rice plants that were sprayed with benzoic acid at $20 \mathrm{mM}$ showed the maximum increase in the total photosynthetic pigments, the highest increase in the total carbohydrate content and the protein content of the yielded grains. This increase could be attributed to the anti-B. oryzae effect of benzoic acid or salicylic acid as discussed previously. Based on these results we recommended applying these treatments in order to control the brown spot disease of rice as alternative to chemical fungicides due to its safety, effectiveness and inexpensiveness.

\section{ACKNOWLEDGMENTS}

The field experiment described in this paper was carried out at Tag El-Ezz Agricultural Research Station, Mansoura, Egypt. We thank Prof. Dr. Ibrahim Othman for agronomic help and valuable suggestions. Greeting and sincere thanks to Plant Pathology Dept., Mansoura Univ., Egypt, for the excellent technical support during the course of this study. Our deep gratitude is also extending to Dr. Khalid Ghoneem for his sincere help in the fungal identifications.

\section{RESUMO}

\section{Controle da macha-parda do arroz (Bipolaris oryzae) pelo emprego de antioxidantes fenólicos}

Bipolaris oryzae é o agente causador da doença manchaparda do arroz e é responsável por significativas perdas econômicas. Três antioxidantes fenólicos (ácido salicílico, ácido benzóico e hidroquinona) foram avaliados para o controle dessa doença do arroz. A atividade antifúngica destes compostos foi avaliada in vitro contra $B$. oryzae em diferentes concentrações e a eficiência de sua aplicação exógena no controle da manchaparda foi avaliada em condições de campo. Nos ensaios in vitro, os ácidos benzóico e salicílico a 9mM inibiram completamente a multiplicação de $B$. oryzae. Em condições de campo, a aspersão de ácido benzóico a $20 \mathrm{mM}$ causou uma redução significativa na gravidade e incidência da doença na folhas da planta, além de aumentar significativamente o rendimento dos grãos e seus componentes. Algumas respostas bioquímicas foram também observadas, verificando-se que a aplicação do tratamento prévio causou um aumento significativo nos pigmentos fotossintéticos totais (clorofila $a$ e $b$ e carotenóides) nas folhas e no conteúdo de carboidratos e proteínas nos grãos.

Palavras-chave: ácido benzóico, Bipolaris oryzae, hidroquinona, ácido salicílico, resistência sistêmica

\section{REFERENCES}

1. Abbas, E.E.; Ghoneem, K.M.; Ali, A.A.; El-baz, S.M. (2006). Yield maximization and chocolate spot control of some faba bean cultivars by antioxidants. J. Agric. Sci. Mans. Univ., 31, 7605-7615.

2. Aldesuquy, H.S.; Baka, Z.M. (1992). Physiological and biochemical changes in host leaf tissues associated with the growth of two biotrophic fungi growing in Egypt. Phyton Horn., 32, 129-142.

3. Aluko, M.O. (1970). The measurement of brown leaf spot on rice. PANS, 16, 76-81.

4. Bradford, M.M. (1976). A rapid and sensitive method for the quantitation of microgram quantities of protein utilizing the principle of protein-dye binding. Anal. Biochem., 72, 148-154.

5. Cowan, M.M. (1999). Plant products as Antimicrobial agents. Clin Microbiol. Rev., 12, 564-582.

6. Duncan, D.B. (1955). Multiple range and multiple F test. Biometrics, $11,1-42$.

7. El-Wahsh, S.M. (1997). Studies on both brown spot and blast diseases of rice in Egypt. Tanta Univ. Egypt, Ph.D. thesis.

8. El-Wakil, M.; El-Metwally, M. (2000). Hydroquinone, a promising antioxidant for managing seed-borne pathogenic fungi of peanut. Pak. J. Biolog. Sci., 3, 374-375.

9. FAO Statistical databases (2006).

10. Green, S.; Bailey, K.L.; Tewari, J.P. (2001). The infection process of Alternaria cirsinoxia on Canada thistle (Cirsium arvense) and host structural defense responses. Mycol. Res., 105, 344-351.

11. Harborne, J.B. (1984). Phytochemical Methods: a guide modern techniques of plant analysis. Chapman and Hall press, London.

12. Hayat, S.; Ahmad, A. (2007). Salicylic acid: A Plant Hormone. Springer Netherlands.

13. Hedge, J.E.; Hofreiter, B.T. (1962). In: Whistler, R.L., Be Miller, J.N. (ed.), Methods in Carbohydrate Chemistry. New York: Academic Press.

14. ISTA (International Seed Testing Association) (1996). Seed Sci. Technol., 24, 28-42.

15. Mackowiak, P.A. (2000). Brief History of Antipyretic Therapy. Clin. Infect. Dis., 31, 154-156.

16. Mew, T.W.; Gonzales, P. (2002). A handbook of rice seed-borne fungi. Los Banos, Philippines: International Rice Research Institute (IRRI) and Enfield, N.H., USA: Science Publishers, Inc. 83p. 
17. Myers, G.A.; Grinvalds, R.; Booth, S.; Hutton, S.I.; Binks, M.; Kemp, D.J.; Sriprakash, K.S. (2000). Expression of two novel proteins in Chlamydia trachomatis during natural infection. Microb. Pathog., 29, 63-72.

18. SAS Institute (1988). SAS/STAT User's Guide, release 6.03 ed. SAS Institute, Cary, NC.

19. Scalbert, A. (1991). Antimicrobial properties of tannins. Phytochem., $30,3875-3883$.

20. Scarponi. L.; Perucci, P. (1986). The effect of a number of S-triazines on the activity of maize delta arninolivulinate dehydrase. Agrochemica, 30, 6-44.

21. Senaratna, T.; Merritt, D.; Dixon, K.; Bunn, E.; Touchell, D.; Sivasithamparam, K. (2003). Benzoic acid may act as the functional group in salicylic acid and derivatives in the induction of multiple stress tolerance in plants. Plant Growth Regul., 39, 77-81.
22. Shahda, W.T. (2000). The use of antioxidants for control of tomato damping off. Alex. J. Agric. Res., 45, 307-316

23. Soylu, S.; Bennett, M.H.; Mansfiels, J.W. (2002). Induction of phytoalexin accumulation in broad bean (Vicia faba L.) cotyledons following treatments with biotic and abiotic elicitors. Turk. J. Agric., 26, 343-348.

24. Talieva, M.N.; Kondrat'eva, V.V. (2002). Influence of exogenous salicylic acid on the level of phytohormones in tissues of Phlox paniculata and Phlox setacea leaves with special reference to resistance against the powdery mildew causative agent Erysiphe cichoracearum DC. f. phlogis Jacz. Biology Bulletin, 29, 551-554.

25. Yalpani, N.; Leon, J.; Lawton, M.; Raskin, I. (1993). Pathway of salicylic acid biosynthesis in healthy and virus-inoculated tobacco. Plant Physiol., 103, 315-321. 